\title{
Nadir bir ERCP komplikasyonu nedeniyle olgu sunumu; retroperitoneal perforasyon
}

\author{
Case report of a rare endoscopic retrograde cholangiopancreaticography complication: \\ Retroperitoneal perforation
}

(D) Pınar YILDIZ1 ${ }^{1}$, (D Tuncer TEMEL², (D Erkin ÖZTAŞ², (D) Selçuk DişiBEYAZ²

Osmangazi Üniversitesi Tip Fakültesi, Iç Hastalılan Anabilim Dall, ${ }^{1}$ Genel Dahiliye Bilim Dall, ${ }^{2}$ Gastroenteroloji Bilim Dalı, Eskişehir

Endoskopik retrograd kolanjiyopankreatografi, pankreatobiliyer hastalıklarda tanı ve tedavi amaçlı çok sık kullanılan bir yöntemdir. Hastaya ve işleme bağlı olarak pankreatit, kanama ve perforasyon gibi birtakım komplikasyonlar görülebilir. Burada 79 yaşında bilinen kronik obstrüktif akciğer hastalığı öyküsü olan ve farklı bir merkezde koledokta taş nedenli uygulanan endoskopik retrograd kolanjiyopankreatografi işleminden yaklaşı 1,5 ay sonra genel durumunda ve beslenmesinde progresif bozulma yaşayan bir hasta sunuldu. Hastanın görüntüleme tetkiklerinde retroperitoneal perforasyon düșündüren bulgular ile birlikte karın ve sirtında cilt altında yaygın ve ayn zamanda alt ekstermitede ciddi ödem, eşlik eden sellülit mevcuttu. Takibinde hasta sepsis ve multiorgan yetmezliği ile kaybedildi. Endoskopik retrograd kolanjiyopankreatografi işlemi tanısal ve tedavi amaçlı sıklıkla uygulanan ve hayat kurtarıcı olarak da bașvurulan bir yöntemdir. Bununla birlikte ișlem sırasında, erken ve geç dönemde gelişebilecek komplikasyonlar açısından dikkatli olunmalı ve hastalar titizlikle takip edilmelidir.

Anahtar kelimeler: ERCP, komplikasyon, retroperitoneal perforasyon
Endoscopic retrograde cholangiopancreaticography is a frequently used method for diagnosis and treatment of pancreatobiliary diseases. Depending on the patient and the procedure, a number of complications, such as pancreatitis, bleeding, and perforation, may occur. Here we present a 79-yearold patient who has a history of a known chronic obstructive pulmonary disease and suffers from progressive deterioration in his general condition. He has started to feed approximately 1.5 months after undergoing endoscopic retrograde cholangiopancreaticography procedure, which was performed in a different center due to the presence of a choledochal stone. As observed on imaging studies, the patient had signs of retroperitoneal perforation and extensive edema of the abdomen and the back under the skin, along with severe edema of the lower extremity and accompanying cellulitis. In the follow-up, the patient died because of sepsis and multiorgan failure. Endoscopic retrograde cholangiopancreaticography is a frequently applied procedure for diagnostic and therapeutic purposes and is used as a life-saving method. However, during the procedure, care should be taken in terms of early and late complications and the patients should be followed up carefully.

Keywords: ERCP, complication, retroperitoneal perforation

polikliniğine başvurdu. Hastanın öyküsünde polikliniğimize başvurusundan 1,5 ay önce farklı bir merkezde akut taşlı kolesistit ve koledokta taş nedenli ERCP yapılmış olduğu, işlemin tamamlanmasının hemen sonrasinda solunum arresti olduğu ve resüsitasyona cevap verdiği, 2 hafta hastanede yatış öyküsünün olduğu ve haliyle taburcu edildiği öğrenildi. Taburculuk sırasında da tam iyileşmesi olmayan ve hastanemiz Iç Hastalıkları Genel Dahiliye polikliniğine başvurduğu sırada genel durumu kötü olan, sırt ağrısı ve beslenme bozukluğu tarifleyen hasta kliniğimize yatırıldı. Yatışında vital bulgularında hipotansiyon ve subfebril ateş, fizik muayenesinde de batın distansiyonu, hassasiyet ve alt ekstremitede ciddi godeli ödem dikkat çekmekteydi. Hastanın laboratuvar bulgularında patolojik olarak; potasyum (K): $3.34 \mathrm{mEq} / \mathrm{L}$, albümin: 1.9g/dL, C-reaktif protein (CRP): $64.5(0-5) \mathrm{mg} / \mathrm{L}$, prokalsitonin: $1.23(0-0.5) \mathrm{ng} /$ $\mathrm{mL}$, hemoglobin (Hgb): 8.7g/dL, lökosit: $15.000 \mathrm{~mm}^{3}$, uluslararası normalleştirilmiş oran (INR): 1.6 olarak tespit edildi. Uygun spektrumda antibiyotik, sivı ve elektrolit replasmanı ve beslenme desteği planlandı. Hasta önce servise, sonrasında da yatışının ikinci günü ateşinin çııması, hemodinamik instabilite nedenli yoğun bakım ünitesine çekildi. 
Abdominal tomografisinde; karaciğer, safra yolları ve koledok normal görülmekle birlikte, pelvik lojda intestinal anslar içinde loküle sıvı ve gluteal kas grubu içinde de loküle koleksiyon dikkat çekmekteydi (Resim 1). Hasta ERCP işlemi sonrası perforasyon? retroperitoneal perforasyon açısından gastroenteroloji ve genel cerrahi klinikleri ile yaygın ödem, sellülit bulguları, nekrotizan fasiit? ile ilişkili enfeksiyon hastalıkları, dermatoloji ve genel cerrahi klinikleri ile ortak takip edildi (Resim 2). Hastanın kliniğinin maksimum destek tedavi dışında cerrahi işleme müsaade etmemesi nedeniyle cerrahi planlanamadı ve yatışının 18. gününde multiorgan yetmezliği ve sepsis tabloları ile kaybedildi.

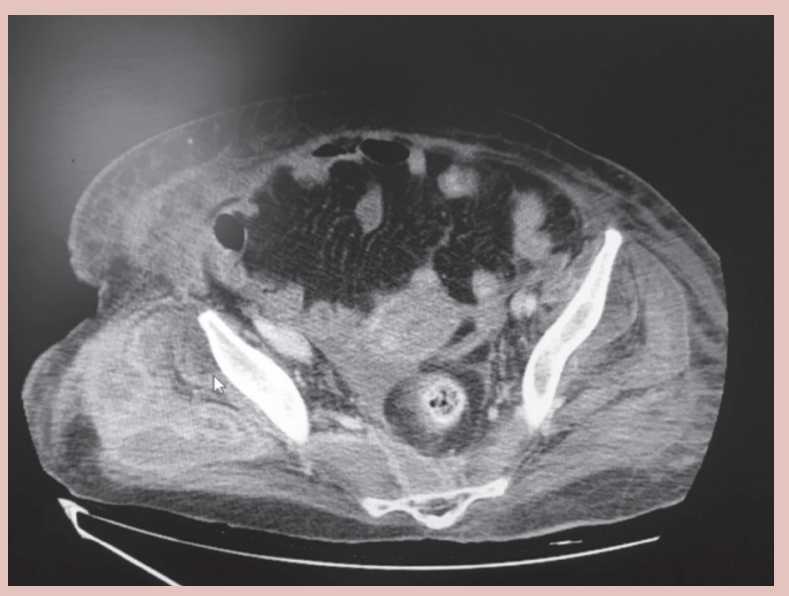

Resim 1. Pelvik lojda intestinal anslar içinde loküle sıvı ve gluteal kas grubu içinde loküle koleksiyon

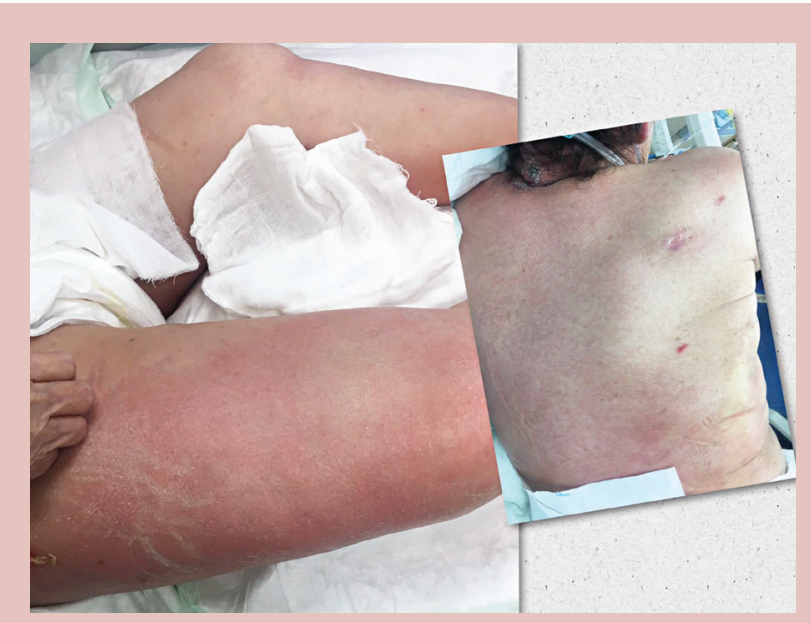

Resim 2. Komplikasyon nedeniyle hastada görülen yaygın ödem, selülit ve nekrotizan fasiit?

\section{TARTISMA}

ERCP ilişkili perforasyon nadir görülen ancak ölümcül seyredebilen bir komplikasyondur. ERCP ilişkili perforasyon; endoskopla lümen perforasyonu, sfinkterotomi sonrası safra kanalının veya pankreatik kanalın intramural bölümünden retroperitoneal sızıntısı, kılavuz tellerin ekstramural geçişi veya stentlerin göçü mekanizmaları ile gelişebilir (3). ERCP sonrası gelişen perforasyon etiyolojisinde, Oddi sfinkter disfonksiyonu, Billroth 2 operasyonu öyküsü gibi anatomik durumlar, işlem süresinin uzun oluşu, kas içi kontrast madde enjeksiyonu, biliyer darlık dilatasyonu, endoskopistin deneyimi gibi işlem ilişkili faktörler bildirilmiştir (4). Hasta ile ilgili gelişmiş komplikasyon ile ilişkili en önemli risk faktörleri, ileri yaş ve kadın cinsiyettir. Bununla beraber uzun ylllardır tedavi altında olduğu KOAH tanısı da mevcuttur $(2,3)$. 9383 olgunun değerlendirildiği bir çalışmada ERCP ilişkili perforasyon tespit edilen 29 hastanın yaş ortalaması 70.5'dur (1). Perforasyon gelişiminde ileri yaş riski arttırmakta iken, post-ERCP pankreatit gelişmesinde genç yaş risk artışı ile ilişkilendirilmiştir (2). Bizim olgumuz 79 yaşında ve bayan olarak perforasyon ile ilişkili risk faktörlerini taşımakta idi. Klinikte bu olgularda karın ve sırt ağrısı, subkutan dokuda amfizem ve ödem, ateş ve taşikardi yakınmaları saptanabilir (5). Olgumuzda da detaylı sorgulandığında karında huzursuzluk, distansiyon ve sırt ağrısı mevcuttu. İslem sırasında ya da işlemden hemen sonra perforasyondan şüphelenildiğinde floroskopi altında kontrast madde enjeksiyonu ile perforasyon tespit edilebilir. Kontrast madde ekstravazasyonu saptanamayan olgularda oral kontrastlı abdominal tomografi diğer bir tanısal yöntemdir. İşlem sonrasında süre geçtikçe gelişen inflamasyon perforasyon tanısını güçleştirmektedir (3). ERCP komplikasyonları işlem anında, işlem sonrası ilk 30 günde erken dönemde ve 30 günden sonra geç dönemde görülebilmektedir. Bu nedenle bu olgularda morbidite ve mortaliteyi önleyen en önemli faktör perforasyondan şüphelenmek ve erken tanı koyabilmektir. Hastamızda ERCP işleminin ardından sırt ağrısı ve iştahsızlık progresif olarak artmış ancak hasta yaklaşık 45 gün sonra hastaneye başvurmuştur ve bu nedenle de tanıyı net ortaya koyabilmek mümkün olmamıştır. Bu da tanı koyabilmek ve morbidite ve mortaliteyi önlemek için geç bir süredir.

Stapfer ve ark. tanısal olarak lokalizasyonun belirlenmesi ve tedavinin yönetilmesi amaçlı duodenal perforasyonları dörde ayırmıştır. Tip I; intra ve retroperitoneal alana kontrast madde kaçışının görüldüğü, Tip II; Ampulla Vateri içindeki perforasyonlardır. Tip III; distal koledok perforasyonlarıdır. Tip II ve III gruplarındaki hastalar çoğunlukla tıbbi tedavi ve takibe olumlu cevap vermektedirler. Tip IV olgular ise retroperitoneal hava saptanan olgulardır ve benign seyirlidir (6).

ERCP sonrasinda perforasyon tedavisini planlarken; hastanın yaşı, komorbiditeleri, klinik durumu, perforasyon tipi ve alanı, radyolojik bulgular ve tanı konulması ve cerrahi planlanması arasında geçen süre belirleyici olmaktadır $(1,7)$. Bazı hastalarda sıvı elektrolit desteği ve antibiyotik ile yakın takip ve konservatif tedavi uygulanmakta iken bazı hastalarda hızla cerrahi planlanmakta ve bu konuda klinisyenin, genel cerrah ve anestezi ekibinin ortak karar vermesi önerilmektedir 
$(1,8)$. Bizim hastamızda da olduğu gibi hastalarda mortalite sepsis ve multi organ yetmezliği ile görülmektedir. Ne yazık ki hastaların tanılarının konulmasında karşılaşılan güçlükler ve buna bağlı cerrahi işlem süresinin gecikmesi, inflamasyon nedenli normal anatominin bozulması, cerrahi yapilsa bile intra ve retroperitoneal perforasyon yerinin tespit edilemeyişi de tedaviyi güçleştirmektedir (1).

Retroperitoneal perforasyon intraabdominal perforasyonlardan farklı olarak saatlerden günlere uzanabilen sürelerde tanı

\section{KAYNAKLAR}

1. Tavusbay C, Alper E, Gokova M, et al. Management of perforation after endoscopic retrograde cholangiopancreatography. Ulus Travma Acil Cerrahi Derg 2016;22:441-8.

2. Freeman ML. Complications of endoscopic retrograde cholangiopancreatography: avoidance and management. Gastrointest Endosc Clin N Am 2012;22:567-86.

3. ASGE Standards of Practice Committee, Chandrasekhara V, Khashab MA, et al. Adverse events associated with ERCP. Gastrointest Endosc 2017;85:32-47.

4. Guerra F, Giuliani G, Coletta D, Bonapasta SA, Levi Sandri GB. Clinical outcomes of ERCP related retroperitoneal perforations. Hepatobiliary Pancreat Dis Int 2017;16:160-3.

5. Cho KB. The management of endoscopic retrograde cholangiopancreatography: related duodenal perforations. Clin Endosc 2014;47:341-5. alabilmektedir. Literatürde özellikle bu olgularda subkutan dokuda amfizem, yaygın ödem ve sırt ağrısı ile bildirilmiştir (9). Olgumuz perforasyon düşünülen ve 45 gün kadar gecikmiş döneme sağ kalım göstermiş nadir bir olgudur.

Sonuç olarak ERCP ilişkili perforasyon nadir de olsa oldukça ciddi ve fatal seyredebilen bir komplikasyondur. Özellikle yaşlı ve komorbiditeleri olan hastaların takiplerinin dikkatli yapılması, olgu bazlı değerlendirilmeleri ve klinisyenlerin dinamik davranmaları oldukça önemlidir.

6. Howard TJ, Tan T, Lehman GA, et al. Classification and management of perforations complicating endoscopic sphincterotomy. Surgery 1999;126:658-65

7. Wu HM, Dixon E, May GR, Sutherland FR. Management of perforation after endoscopic retrograde cholangiopancreatography (ERCP): a population-based review. HPB (Oxford) 2006;8:393-9.

8. Li G, Chen Y, Zhou X, Lv N. Early management experience of perforation after ERCP. Gastroenterol Res Pract 2012;2012:657418.

9. Beaudoin FLl, Valente JH. Delayed post-endoscopic retrograde cholangiopancreatography perforation presenting as scrotal subcutaneous emphysema. J Emerg Med 2011;40:e15-7. 